Article

\title{
Treatment of Winery Wastewater with a Multistage Constructed Wetland System for Irrigation Reuse
}

\author{
Mirco Milani ${ }^{1}{ }^{\circledR}$, Simona Consoli ${ }^{1, *} \mathbb{C}$, Alessia Marzo ${ }^{2}$, Alessandra Pino ${ }^{1}$, \\ Cinzia Randazzo ${ }^{1}$ (D), Salvatore Barbagallo ${ }^{1}$ and Giuseppe Luigi Cirelli ${ }^{1}$ (D) \\ 1 Department of Agricultural, Food and Environment (Di3A), University of Catania, Via S. Sofia 100, \\ 95123 Catania, Italy; mirco.milani@unict.it (M.M.); alessandra.pino@unict.it (A.P.); \\ cinzia.randazzo@unict.it (C.R.); salvo.barbagallo@unict.it (S.B.); giuseppe.cirelli@unict.it (G.L.C.) \\ 2 Centre for the Conservation and Management of Nature and Agroecosystems (CUTGANA), University of \\ Catania, Via S. Sofia 100, 95123 Catania, Italy; alessia.marzo@unict.it \\ * Correspondence: simona.consoli@unict.it; Tel.: +39-095-714-7547
}

Received: 15 March 2020; Accepted: 27 April 2020; Published: 29 April 2020

\begin{abstract}
This paper reports a study on the performance of a multistage constructed wetland (CW) system adopted for winery wastewater and on the analysis of its suitability for irrigation reuse. The CW system treats about $3 \mathrm{~m}^{3} \cdot \mathrm{day}^{-1}$ of wastewater produced by a small winery located in Sicily (insular Italy). Wastewater samples were collected at the CW inlet and outlet for physical-chemical and microbiological quality characterization. CW efficiency was evaluated on the basis of water quality improvement and of the achievement of Italian and EU irrigation reuse regulation limits. The CW system showed Chemical Oxygen Demand (COD) and Total Suspended Solids (TSS) mean removal rates of about $81 \%$ and $69 \%$, and a maximum removal of about $99 \%$ (for both COD and TSS) occurred during grape harvest phase. The $\mathrm{CW}$ removal efficiencies for nutrients were $56 \%$ for $\mathrm{TN}$ and $38 \%$ for $\mathrm{PO}_{4}-\mathrm{P}$, considering their low average concentrations at $\mathrm{CW}$ inlet. The $\mathrm{CW}$ system evidenced an effluent average quality compatible with the limits imposed by the Italian regulation and EU proposal regulation on the minimum requirement for water reuse. The $\mathrm{CW}$ vegetated area showed regular growth and vegetative development; phytotoxicity phenomena were not detected. The results of the study suggest the important role of CW systems in the treatment of winery wastewater and for their subsequent reuse in agriculture.
\end{abstract}

Keywords: multistage constructed wetland; winery wastewater; wastewater reuse; semi-arid climate

\section{Introduction}

The wine sector occupies a prominent position in the Italian agri-food industry, being the most important in the beverage sector. The latest estimates by the International Organization of Vine and Wine indicate that Italy is the world's largest wine producer with a production of 46.6 million hectoliters of the 263 million hectoliters of world wine production [1]. Considering that the vinification process generates wastewater volumes higher than wine production (from $1 \mathrm{~L}$ of wine, about 1.6-2.0 L of wastewater are produced) [2], the annual quantities of winery wastewater produced in Italy reach 10 million cubic meters. Therefore, there is a need to improve the sustainability of winery wastewater disposal; in fact, if not controlled, such disposal, although it contains mainly non-toxic organic polluting waste, can have a negative impact on natural ecosystems, with their consequent alteration [3-5]. Winery wastewaters are characterized by high concentrations of organic matter, with Chemical Oxygen Demand (COD) varying between about 300 and 50,000 mg. $\mathrm{L}^{-1}$ [4], Biological Oxygen Demand $\left(\mathrm{BOD}_{5}\right)$ between about $40 \%$ and $90 \%$ of the COD value $[5,6]$, and Total Suspended Solids (TSS) ranging between 190 to $18,000 \mathrm{mg} \cdot \mathrm{L}^{-1}[6,7]$. 
Due to these high variations in quantity and quality, associated with the generally low nutrient content, a variable $\mathrm{pH}$ (from 3.5 to 8 ), and a phytotoxicity and microbial inhibition by toxic organic and inorganic compounds [2,4,8,9], conventional wastewater treatment systems (WWT) are generally ineffective [10]. In addition, particularly in the case of small wineries (10-49 employees and assets of 3-10 million euros) [11], WWTs are expensive and require qualified personnel for O\&M.

From this perspective, natural wastewater treatment systems, such as constructed wetlands $(\mathrm{CW})$, represent an effective solution to fulfill legal requirements while requiring low O\&M costs. This treatment option is particularly suitable for small wineries, where the annual production of wastewater and the availability of financial resources may not be sufficient to guarantee expensive physical, chemical, or biological WWT [12,13].

Although several studies have shown the efficiency of CW for the treatment of agro-industrial wastewater [2,14-16], only a few applications are known to us for the reuse of wastewater from wineries.

In semi-arid climatic conditions, such as in southern Italy, it is desirable to reuse wastewater in order to increase the water resources available to the agricultural sector, which is currently facing a strict limitation. However, in Italy, the water reuse for irrigation is limited due to the strict rules imposed by the national law (Ministerial Decree 185/2003) [17], which does not distinguish between types of crops or methods of irrigation. Again, CWs can represent one of the few economically sustainable solutions for smaller wineries that want to use reclaimed water for irrigation.

The aim of the study is to assess the performance of a multistage CW system for winery wastewater treatment and reuse for irrigation. The study intends to promote the use of $\mathrm{CW}$ treatment systems in the wine sector of semi-arid Mediterranean environments.

\section{Materials and Methods}

\subsection{The Experimental Multistage CW System}

The research was conducted in a multistage pilot CW system, located in the semi-arid southeastern Sicily (latitude $36^{\circ} 45^{\prime} \mathrm{N}$, longitude $15^{\circ} 01^{\prime} \mathrm{E}$, altitude $60 \mathrm{~m}$ ), which is used for the treatment of a portion of the wastewater produced by the Marabino winery (production capacity of approximately $\left.1500 \mathrm{hL} \cdot \mathrm{year}^{-1}\right)$. The wastewater from the winery is mixed with the sewage produced by the toilets used by employees and visitors.

Winery wastewater (about $3 \mathrm{~m}^{3} \cdot$ day $^{-1}$ ) is subjected to a pre-treatment phase (coarse screening) followed by an Imhoff tank, an equalization tank $\left(5 \mathrm{~m}^{3}\right)$, and a multistage CW (Figure 1); then the effluent is disposed on the ground through a sub-irrigation system. The CW has a total area of about $230 \mathrm{~m}^{2}$ and consists of a vertical subsurface flow bed (VF) $\left(140 \mathrm{~m}^{2}\right)$ followed by a horizontal subsurface flow bed (HF) $\left(60 \mathrm{~m}^{2}\right)$ and a free surface flow unit (FSF) $\left(30 \mathrm{~m}^{2}\right)$. The treated wastewater volume was measured with a flow meter.

The CW beds were excavated and covered with a $4 \mathrm{~mm}$ thick bentonite layer to avoid leaks due to infiltration. The banks of the CW beds had been covered with jute nets to facilitate the growth of vegetation.

The VF bed was filled, from the bottom to the surface, with gravel of the following sizes: $25-40 \mathrm{~mm}$ for a depth of $0.40 \mathrm{~m}, 10-15 \mathrm{~mm}$ for a depth of $0.15 \mathrm{~m}, 5-10 \mathrm{~mm}$ for a depth of $0.15 \mathrm{~m}$, and 2-5 mm for a depth of $0.15 \mathrm{~m}$; washed sand was used for a depth of $0.10 \mathrm{~m}$ followed by gravel size of $2-5 \mathrm{~mm}$ for a depth of $0.05 \mathrm{~m}$ (Figure 2). The equalization tank was equipped with a pump activated by an electronic timer for intermittent loading of the VF (five minutes every four hours and about $0.5 \mathrm{~m}^{3}$ for each loading). Wastewater was distributed over the surface of the bed by a network of pressurised perforated pipes fed through a manifold by the pump. Wastewater was collected in a drainage pipes system placed at the bottom of the bed. Passive aeration is encouraged with four perforated pipes placed along the bottom and sides and extended approximately $0.50 \mathrm{~m}$ over the surface of the bed. The VF CW bed was planted with Phragmites australis L. at a density of four rhizome $\mathrm{m}^{-2}$. 


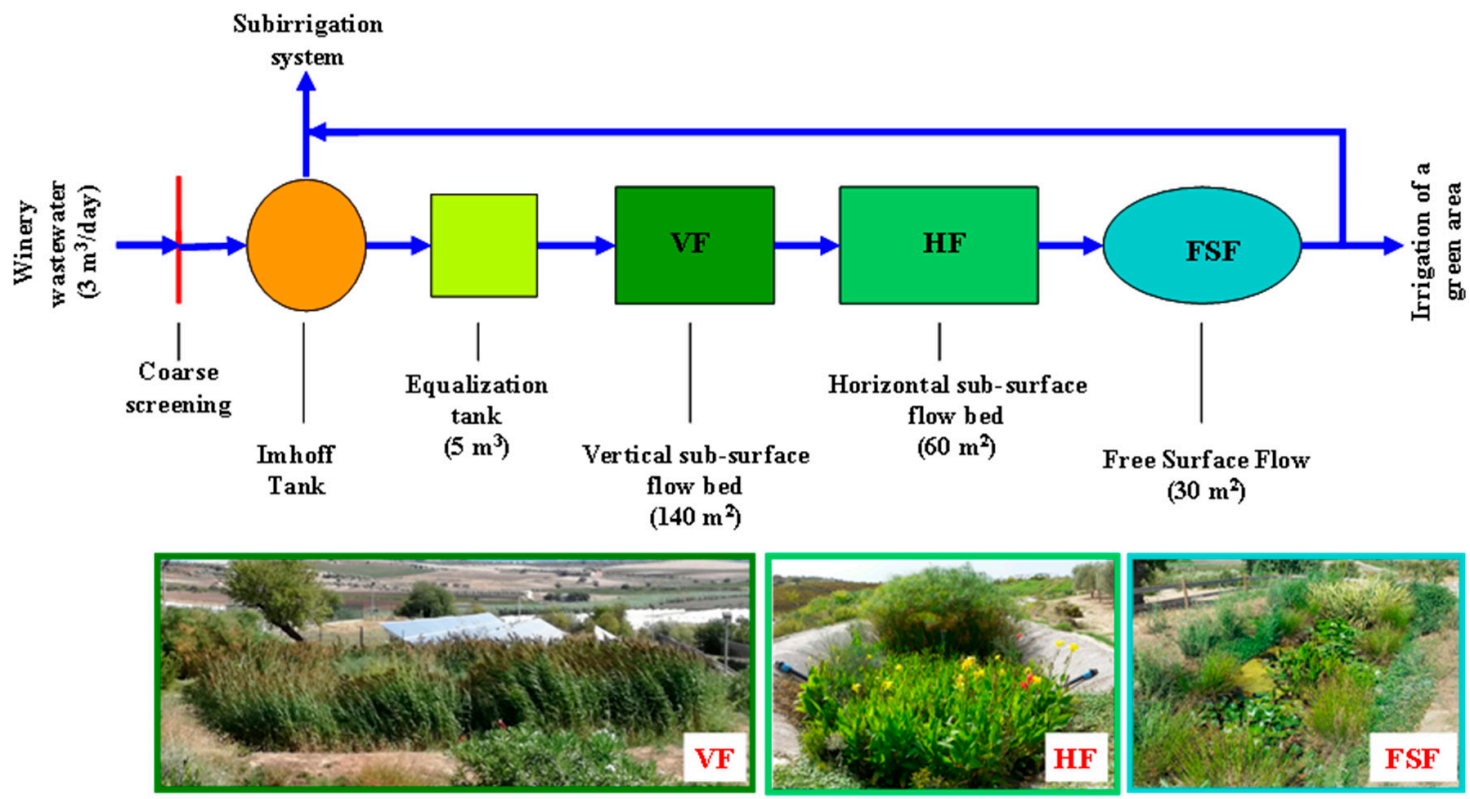

Figure 1. Layout of the multistage pilot constructed wetland (CW) located at the Marabino winery (Sicily, Italy).

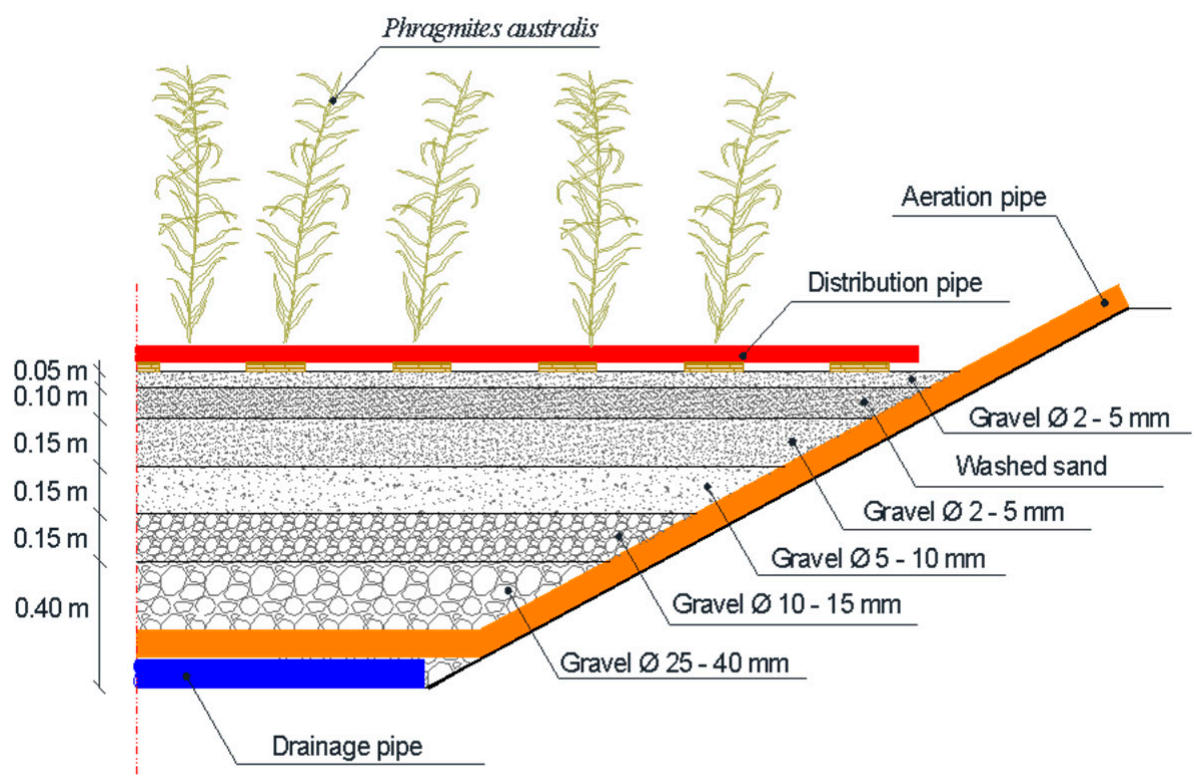

Figure 2. Section of the vertical subsurface flow bed (VF) located at the Marabino winery.

The HF CW bed has a nominal hydraulic retention time (HRT) of about $110 \mathrm{~h}$ and was filled, to an average height of $0.60 \mathrm{~m}$, with calcareous gravel (diameter 8-10 $\mathrm{mm}$ ) and, in the initial and terminal section, with 80-100 mm of coarse volcanic gravel to prevent clogging and improve homogenous flow distribution (Figure 3). The first half of the bed was planted with Cyperus Papyrus var. Siculus (8 plants $\mathrm{m}^{-2}$ ) and the second half with Canna indica L. $\left(8\right.$ plants $\left.\mathrm{m}^{-2}\right)$.

The water depth in the FSF CW was about $0.70 \mathrm{~m}$ with a nominal HRT of about $90 \mathrm{~h}$. The end of FSF's section (i.e., the last $1.5 \mathrm{~m}$ of system) functions as a subsurface flow (filled with coarse volcanic gravel of 80-100 mm) and was planted with 10 plants of Iris pseudacorus L. (Figure 4). In the bottom and in the banks of the FSF CW, there were, respectively, 12 plants of Nymphaea alba L. and 10 plants of Scirpus lacustris L. 

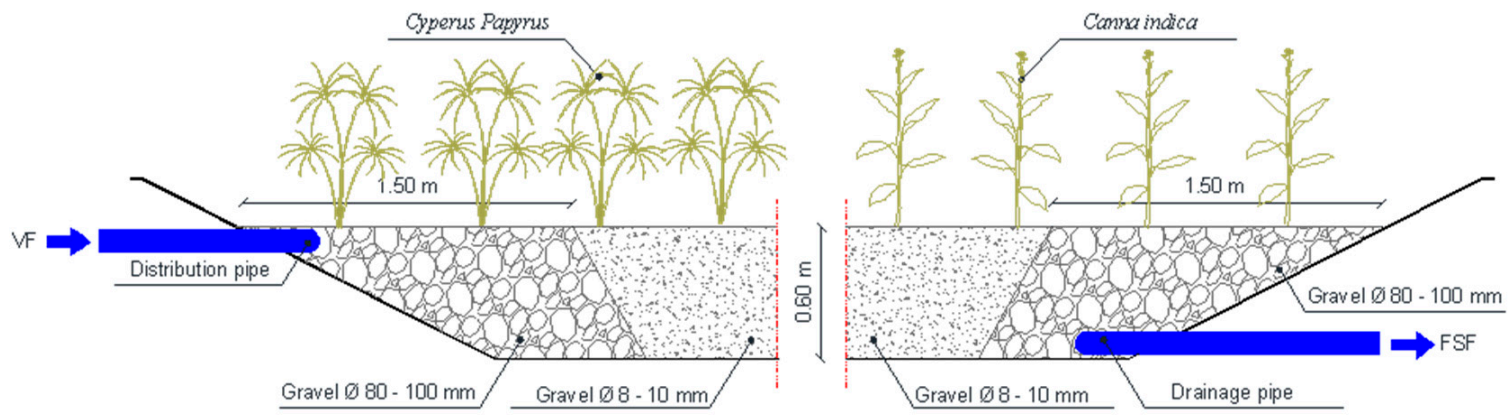

Figure 3. Section of the horizontal subsurface flow bed (HF) located at the Marabino winery.

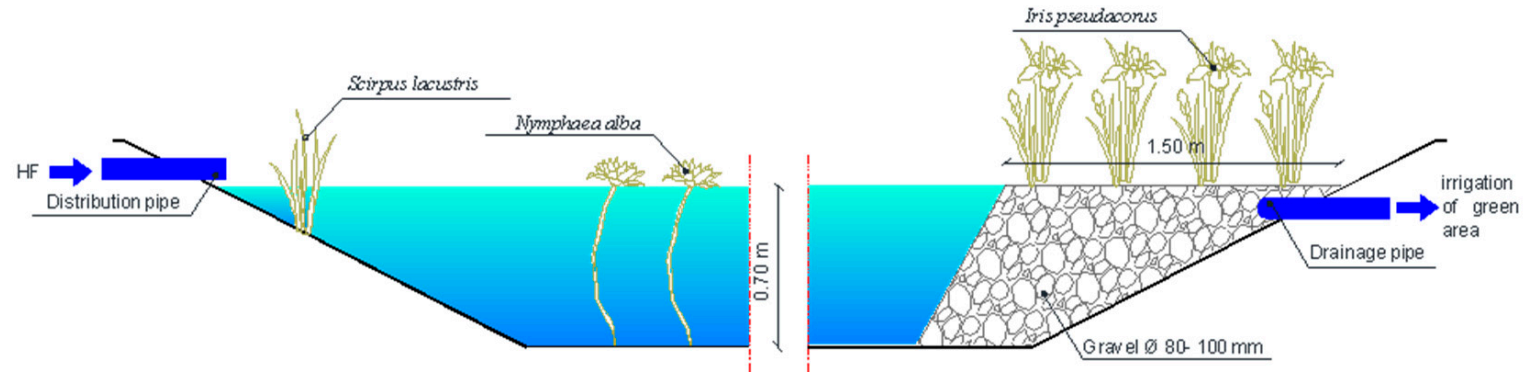

Figure 4. Section of the free surface flow unit (FSF) CW bed located at the Marabino winery.

The planting density was determined according to further previous experiences carried out in similar environments $[18,19]$, and adopting higher density values for the species with lower propagation capacity [20].

After plantation of vegetation (October 2013), the VF and HF units were maintained in saturated conditions until February 2014 to allow the rooting and growth of seedlings. In the first year of operation, only the Phragmites australis showed stunted growth due to the low nutrient concentrations in the treated wastewater. For this reason, at the beginning of the second growth season (March 2015), about $9.9 \mathrm{~g} \cdot \mathrm{m}^{-2}$ of urea fertilizer (N $46 \%$ ) was applied in the VF CW, determining a complete plant cover in June 2015.

Finally, the effluent was used for irrigation of a green area (about $1000 \mathrm{~m}^{2}$ ), close to the multistage CW, vegetated with Punica granatum, Gaura spp., Phyllirea spp., Pistacia lentiscus, Nerium oleander, Convolvulus spp., Rosmarinum spp., Teucrium spp., Laurus nobilis, Ficus carica, Lavandula angustifolia.

\subsection{Wastewater Quality Characterization}

Wastewater quality parameters were monitored from March 2014 to June 2018 with a frequency of 1 to 3 months according to the operations carried out in the winery. Monthly monitoring frequency was chosen during the harvest periods, between August and October.

A total of 104 wastewater samples were taken at the inlet and outlet of the CW beds to analyse the following physico-chemical parameters according to standard methods [21]: $\mathrm{pH}$, Electrical Conductivity (EC), TSS at $105{ }^{\circ} \mathrm{C}, \mathrm{BOD}_{5}, \mathrm{COD}$, Total Nitrogen (TN), Ammonia Nitrogen $\left(\mathrm{NH}_{4}-\mathrm{N}\right)$, Nitrite Nitrogen $\left(\mathrm{NO}_{2}-\mathrm{N}\right)$, Nitrate Nitrogen $\left(\mathrm{NO}_{3}-\mathrm{N}\right)$, Organic Nitrogen $\left(\mathrm{N}_{\text {org }}\right)$, and Orthophosphates $\left(\mathrm{PO}_{4}-\mathrm{P}\right)$. Microbiological analyses were conducted according to Standard Methods for the Examination of Water and Wastewater [22] and following the method described by Russo et al. [23]. Faecal indicator bacteria (Escherichia coli, total coliforms, and enterococci) were enumerated according to the ISO procedures [24], and results were expressed as $\log _{10}$ colony-forming units (CFU) per unit of volume.

For the physico-chemical parameters, the removal efficiency $(R, \%)$ was calculated as follows:

$$
\mathrm{R}=\frac{\left(\mathrm{C}_{\text {in }}-\mathrm{C}_{\text {out }}\right)}{\mathrm{C}_{\text {in }}} \times 100
$$


where $C_{\text {in }}$ and $C_{\text {out }}$ are, respectively, the concentrations at inlet and outlet $\left(\mathrm{mg} \cdot \mathrm{L}^{-1}\right)$. Two important parameters for the empirical design of CW systems, such as Surface Loading Rate (SLR) and Surface Removal Rate (SRR), were determined. These parameters define the amount of pollutant that is being treated or removed per unit surface. The relationship between SLR and SRR is important for determining the wetland surface area needed to meet the discharge target. SLR and SRR were calculated as follows [5]:

$$
\begin{gathered}
\text { SLR }=\frac{\left(Q \times C_{\text {in }}\right)}{A} \\
\text { SRR }=\frac{Q \times\left(C_{\text {in }}-C_{\text {out }}\right)}{A}
\end{gathered}
$$

where SLR and SRR were in $\mathrm{g} \cdot \mathrm{m}^{-2} \cdot$ day $^{-1}, \mathrm{Q}$ is the influent flow rate $\left(\mathrm{m}^{3} \cdot \mathrm{day}^{-1}\right)$ to the $\mathrm{CW}$ system, $\mathrm{C}_{\text {in }}$ is the inlet concentration $\left(\mathrm{g} \cdot \mathrm{m}^{-3}\right), A$ is the $C W^{\prime}$ s area $\left(\mathrm{m}^{2}\right)$, and $C_{\text {out }}$ is the outlet concentration $\left(\mathrm{g} \cdot \mathrm{m}^{-3}\right)$.

Microbiological data were analysed by ANOVA (One-way Analysis of Variance) using Tukey's post-hoc test in order to assess the overall differences among samples. Statistical analysis was performed using XLSTAT PRO 5.7 (Addinsoft, New York, NY, USA), and the reference level of significance was 0.05 in all the assays.

The quality of the effluent of the CW system was also assessed in terms of achieving the standards defined by Italian law [17] and EU proposal regulation on the minimum requirement for water reuse [25].

\subsection{Plant Measurements}

For every December in the period 2014-2017, plant density and aboveground biomass of Phragmites australis, Cyperus papyrus, and Canna indica were measured on three $1 \mathrm{~m}^{2}$ sampling areas selected at the opposite ends and in the middle of each area occupied by the plant species. Accordingly, three sampling areas were identified in VF (Phragmites australis) and six areas in HF (Cyperus papyrus and Canna indica). The bio-agronomic parameters were measured in the whole sampling areas. Dry biomass was evaluated by drying the fresh biomass samples in a thermo-ventilated oven at $65{ }^{\circ} \mathrm{C}$ until a constant weight was reached.

The bio-agronomic results were analysed using ANOVA and Student-Newman-Keuls tests after verifying the homogeneity of the variances using the Bartlett test.

The possible symptoms of plant toxicity in the vegetated areas of the CW beds were identified by a careful visual inspection carried out during the study period.

\section{Results and Discussion}

\subsection{Weather Data at the Experimental Site}

The meteorological data for the study site were recorded by a nearby meteorological station of the Sicilian Agrometeorological Information Service (SIAS), located in Noto (latitude $36^{\circ} 50^{\prime} \mathrm{N}$, longitude $15^{\circ} 03^{\prime} \mathrm{E}$, altitude $30 \mathrm{~m}$ ). From the climatic observations, it is possible to observe that the study area is characterized by a typical Mediterranean climate (Csa under the Koppen-Geiger classification) with hot summers and rainfall not well distributed throughout the year; the spring/summer period is the driest (occasional rains), while the autumn/winter period is the rainiest.

Figure 5 shows daily temperature extremes and rainfall from January 2014 to June 2018. Annual rainfall ranged between $468 \mathrm{~mm}$ (in 2014) and $654 \mathrm{~mm}$ (in 2015), with 1220 days of absence of rainfall during the 1643 total days of experimental study; average rainfall during the grape harvest season (August and September) was $84.3 \mathrm{~mm}$. Daily air temperature values ranged between $-1.9^{\circ} \mathrm{C}$ (in January 2017) and $42.3^{\circ} \mathrm{C}$ (in July 2017). The annual average temperatures were comparable among the different years of trial. 




Figure 5. Rain precipitation $(\mathrm{mm})$ and minimum and maximum air temperature $\left({ }^{\circ} \mathrm{C}\right)$ values from January 2014 to June 2018 at the study site.

\subsection{Wastewater Physico-Chemical Parameters}

Table 1 shows the concentrations of the physico-chemical parameters monitored at the CW beds inlet and outlet and the relative removal efficiency percentages. The $\mathrm{pH}$ of the influent varied between 4.67 and 11.06, with the lowest values observed during the harvest periods and the maximum during the winery washing operations with caustic detergents (sodium hydroxide). After the transition to the multistages (CWs) of the treatment, a reduction in the $\mathrm{pH}$ variation interval was observed, with standard deviations (SD) of 1.34 (first stage inlet) and 0.33 (last stage outlet). Similar results have been obtained by other authors [6,26-28], who report $\mathrm{pH}$ values of the $\mathrm{CW}$ effluent nearby neutrality in the presence of acid wastewater and, in particular, during the harvest. The electrical conductivity of the CW influent varied from 561 to $2930 \mu \mathrm{S} \cdot \mathrm{cm}^{-1}$, with average value of $1086 \mu \mathrm{S} \cdot \mathrm{cm}^{-1}$, slightly reduced, of about $15 \%$, after the passage through the multistage CW.

Table 1. Wastewater (WW) quality at the inlet and outlet of each constructed wetland $(\mathrm{CW})$ stage and mean physico-chemical pollutants removal efficiencies (21 samples for each CW stage).

\begin{tabular}{|c|c|c|c|c|c|c|}
\hline \multirow{2}{*}{$\begin{array}{c}\text { WW Main Quality } \\
\text { Characteristics and Location }\end{array}$} & \multirow{2}{*}{ Minimum } & \multirow{2}{*}{ Average } & \multirow{2}{*}{ Maximum } & \multirow{2}{*}{$\begin{array}{l}\text { Standard } \\
\text { Deviation }\end{array}$} & \multicolumn{2}{|c|}{ Removal (\%) } \\
\hline & & & & & Each Stage & All CW \\
\hline \multicolumn{7}{|l|}{$\mathrm{pH}$} \\
\hline Inlet VF & 4.67 & 6.82 & 11.06 & 1.34 & & \\
\hline Outlet VF & 5.08 & 6.96 & 8.32 & 0.66 & & \\
\hline Outlet HF & 6.20 & 7.02 & 7.66 & 0.37 & & \\
\hline Outlet FSF & 6.57 & 7.19 & 7.82 & 0.33 & & \\
\hline \multicolumn{7}{|l|}{$\begin{array}{l}\text { Electrical Conductivity } \\
\left(\mu \mathrm{S} \cdot \mathrm{cm}^{-1}\right)\end{array}$} \\
\hline Inlet VF & 561 & 1086 & 2930 & 584 & & \\
\hline Outlet VF & 510 & 990 & 2040 & 459 & & \\
\hline Outlet HF & 462 & 983 & 1974 & 451 & & \\
\hline Outlet FSF & 433 & 943 & 986 & 411 & & \\
\hline
\end{tabular}


Table 1. Cont.

\begin{tabular}{|c|c|c|c|c|c|c|}
\hline \multirow{2}{*}{$\begin{array}{l}\text { WW Main Quality } \\
\text { Characteristics and Location }\end{array}$} & \multirow{2}{*}{ Minimum } & \multirow{2}{*}{ Average } & \multirow{2}{*}{ Maximum } & \multirow{2}{*}{$\begin{array}{l}\text { Standard } \\
\text { Deviation }\end{array}$} & \multicolumn{2}{|c|}{ Removal (\%) } \\
\hline & & & & & Each Stage & All CW \\
\hline \multicolumn{7}{|l|}{$\mathrm{TSS}\left(\mathrm{mg} \cdot \mathrm{L}^{-1}\right)$} \\
\hline Inlet VF & 8 & 86 & 630 & 130 & & \\
\hline Outlet VF & 5 & 36 & 180 & 40 & 42 & \\
\hline Outlet HF & 2 & 14 & 170 & 20 & 34 & \\
\hline Outlet FSF & 2 & 11 & 31 & 7 & 24 & 69 \\
\hline \multicolumn{7}{|l|}{$\mathrm{BOD}_{5}\left(\mathrm{mg} \cdot \mathrm{L}^{-1}\right)$} \\
\hline Inlet VF & 4 & 316 & 1,243 & 418 & & \\
\hline Outlet VF & 2 & 122 & 500 & 166 & 45 & \\
\hline Outlet HF & 2 & 34 & 144 & 43 & 47 & \\
\hline Outlet FSF & 2 & 17 & 65 & 20 & 29 & 78 \\
\hline \multicolumn{7}{|l|}{$\mathrm{COD}\left(\mathrm{mg} \cdot \mathrm{L}^{-1}\right)$} \\
\hline Inlet VF & 6 & 587 & 2020 & 730 & & \\
\hline Outlet VF & 5 & 221 & 882 & 301 & 45 & \\
\hline Outlet HF & 4 & 74 & 393 & 112 & 51 & \\
\hline Outlet FSF & 3 & 28 & 94 & 37 & 40 & 81 \\
\hline \multicolumn{7}{|l|}{$\mathrm{NH}_{4}-\mathrm{N}\left(\mathrm{mg} \cdot \mathrm{L}^{-1}\right)$} \\
\hline Inlet VF & 0.6 & 3.5 & 15.2 & 3.7 & & \\
\hline Outlet VF & 0.3 & 2.0 & 10.5 & 2.6 & 31 & \\
\hline Outlet HF & 0.2 & 0.9 & 2.8 & 0.6 & 28 & \\
\hline Outlet FSF & 0.1 & 0.7 & 1.6 & 0.3 & 16 & 57 \\
\hline \multicolumn{7}{|l|}{$\mathrm{TN}\left(\mathrm{mg} \cdot \mathrm{L}^{-1}\right)$} \\
\hline Inlet VF & 2.7 & 13.3 & 39.6 & 11.9 & & \\
\hline Outlet VF & 2.1 & 8.3 & 29.4 & 7.1 & 30 & \\
\hline Outlet HF & 1.7 & 5.3 & 26.8 & 5.4 & 29 & \\
\hline Outlet FSF & 1.5 & 4.2 & 24.3 & 4.5 & 15 & 56 \\
\hline \multicolumn{7}{|l|}{$\mathrm{PO}_{4}-\mathrm{P}\left(\mathrm{mg} \cdot \mathrm{L}^{-1}\right)$} \\
\hline Inlet VF & 1.7 & 4.9 & 12.5 & 3.1 & & \\
\hline Outlet VF & 1.5 & 3.4 & 7.6 & 1.5 & 22 & \\
\hline Outlet HF & 1.3 & 3.0 & 5.9 & 1.2 & 11 & \\
\hline Outlet FSF & 1.2 & 2.6 & 4.1 & 0.9 & 11 & 38 \\
\hline
\end{tabular}

VF: vertical flow bed; HF: horizontal flow bed; FSF: frer surface flow bed; TSS: Total Suspended Solids; BOD $_{5}$ : Biological Oxygen Demand; COD: Chemical Oxygen Demand; TN: Total Nitrogen.

As expected for the winery effluent, the fluctuations in the concentrations of TSS (average value of $86 \pm 130 \mathrm{mg} \cdot \mathrm{L}^{-1}$ ), $\mathrm{BOD}_{5}$ (average value of $316 \pm 418 \mathrm{mg} \cdot \mathrm{L}^{-1}$ ) and COD (average value of $587 \pm 730 \mathrm{mg} \cdot \mathrm{L}^{-1}$ ) were observed, with peaks during the various washing operations of fermentation tanks, barrels, and the equipment used for pressing the grapes.

However, the ranges of variations were lower (8-630 for TSS $\mathrm{mg} \cdot \mathrm{L}^{-1}, 4-1243 \mathrm{mg} \cdot \mathrm{L}^{-1}$ for BOD ${ }_{5}$, and 6-2020 $\mathrm{mg} \cdot \mathrm{L}^{-1}$ for COD) compared to those reported in the literature $[2,5,6]$; these values are the direct consequence of the high volume of washing water used at the Marabino winery (4-5 L of washing water vs. $1 \mathrm{~L}$ of wine).

The average removal efficiencies (and SD) for TSS, observed in the multistage CW system, were $42 \% \pm 25 \%$ for $\mathrm{VF}, 34 \% \pm 20 \%$ for $\mathrm{HF}$, and $24 \% \pm 28 \%$ for $\mathrm{FSF}$, with the maximum values corresponding to the peaks of TSS in the influent (VF 78\%, HF 75\%, and FSF 94\%).

The results revealed a clear correlation, for each CW unit, between TSS surface loading rate (SLR) and TSS surface removal rate (SRR) (Figure 6), with correlation factors $\left(\mathrm{R}^{2}\right)$ ranging from 0.8499 (FSF) to 0.9815 (VF). This is in accordance with other research carried out in other wineries $[5,29]$. 


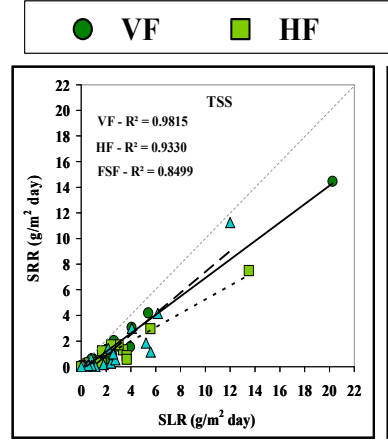

(a)

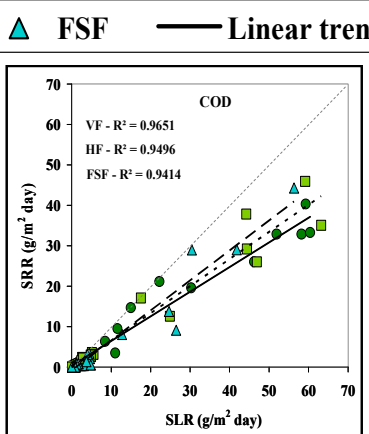

(b)



(c)



(d)

Figure 6. Relationship between surface loading rate (SLR) and surface removal rate (SRR) for Total Suspended Solids (TSS) (a), Chemical Oxygen Demand (COD) (b), Total Nitrogen (TN) (c) and $\mathrm{PO}_{4}-\mathrm{P}$ (d) in each CW unit.

COD values showed a high correlation between SLR and SRR with decreasing $\mathrm{R}^{2}$ values between the first and the last CW unit ( 0.965 for VF, 0.949 for HF, and 0.941 for FSF). The organic loading rate in the VF ranged between 0.08 to $60.38 \mathrm{~g} \mathrm{COD} \mathrm{m}^{-2} \cdot \mathrm{day}^{-1}$, with an average of $15.74 \mathrm{~g} \mathrm{COD} \mathrm{m}^{-2} \cdot \mathrm{day}^{-1}$, comparable with results shown by Masi et al. [30] in small Italian wineries, but quite lower than the $164 \mathrm{~g} \mathrm{COD} \mathrm{m}^{-2}$. day ${ }^{-1}$ reported by Masi et al. [2] in their overview of the experiences at worldwide level during the last 15 years.

Despite these significant differences, the average $\mathrm{CW}$ removal efficiencies of $\mathrm{BOD}_{5}(78 \% \pm 27 \%)$ and COD $(81 \% \pm 25 \%)$ resulted as similar than those reported by Masi et al. [2]. The lower removal of the organic matter shown by FSF ( $29 \%$ for $\mathrm{BOD}_{5}$ and $40 \%$ for COD) is probably due to the low concentrations at inlet (average $\mathrm{BOD}_{5}$ and COD of about 17 and $28 \mathrm{mg} \cdot \mathrm{L}^{-1}$, respectively), associated with the algal bloom phenomenon, only partially removed by filtration at the CW outlet.

The total nitrogen SLR ranged from 0.05 to $3.98 \mathrm{~g} \cdot \mathrm{m}^{-2} \cdot \mathrm{day}^{-1}$, and for VF and HF beds, it seems related to SRR, which has an average value of about 0.19 and $0.28 \mathrm{~g} \cdot \mathrm{m}^{-2} \cdot \mathrm{day}^{-1}$, respectively.

Serrano et al. [5] report similar relationships between SLR and SRR for Total Kjeldhal Nitrogen (TKN) and ammonium in a multistage CW (VF + HF) treating a mixed effluent derived from a winery and a tourist establishment in Spain $\left(\mathrm{R}^{2}=0.9691\right.$ for TKN and $\mathrm{R}^{2}=0.9007$ for $\left.\mathrm{NH}_{3}-\mathrm{N}\right)$. The organic nitrogen was the major fraction (mean value $8.4 \pm 8.1 \mathrm{mg} \cdot \mathrm{L}^{-1}$ ) of TN load (mean value $13.3 \pm 11.9 \mathrm{mg} \cdot \mathrm{L}^{-1}$ ) in the CW system, followed by ammonia (mean value $3.5 \pm 3.7 \mathrm{mg} \cdot \mathrm{L}^{-1}$ ), with a removal efficiency of $57 \%$.

There were no significant differences between the average removal rate of $\mathrm{NH}_{4}-\mathrm{N}$ in VF (31\%) and $\mathrm{HF}(28 \%)$, probably due to the low rate of nitrification in VF, which can result from an insufficient supply of $\mathrm{NH}_{4}-\mathrm{N}$ in the influent (mean concentration of $3.5 \pm 3.7 \mathrm{mg} \cdot \mathrm{L}^{-1}$ ).

As evidenced by the TN and $\mathrm{PO}_{4}-\mathrm{P}$, the relationship between SRR and SLR was lower (maximum $R^{2}=0.8133$ in VF) than that shown for TSS and COD, but higher than that reported by Serrano et al. [5] $\left(\mathrm{R}^{2}=0.4017\right)$, with a similar concentration of $\mathrm{PO}_{4}-\mathrm{P}$ in the $\mathrm{CW}$ influent (about $\left.2.3 \pm 2.1 \mathrm{mg} \cdot \mathrm{L}^{-1}\right)$.

The average nutrient removal efficiency was slightly lower in FSF $\left(11 \%\right.$ for $\mathrm{PO}_{4}-\mathrm{P}$ and $15 \%$ for $\mathrm{TN}$ ) compared to the other two $\mathrm{CW}$ stages. This is probably due to the low values of the average concentrations in the influent $\left(3.0 \mathrm{mg} \cdot \mathrm{L}^{-1}\right.$ for $\mathrm{PO}_{4}-\mathrm{P}$ and $5.3 \mathrm{mg} \cdot \mathrm{L}^{-1}$ for $\left.\mathrm{TN}\right)$, which were very close to the background concentration [31].

\subsection{Microbiological Parameters}

Microbiological counts of E.coli, total coliform, and Enterococcus spp., detected at the inlet and at the outlet of each CW unit, during both harvest ( 3 months) and non-harvest periods ( 9 months), are reported in Figure 7. 


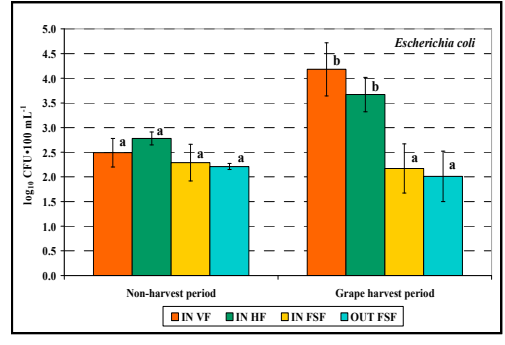

(a)

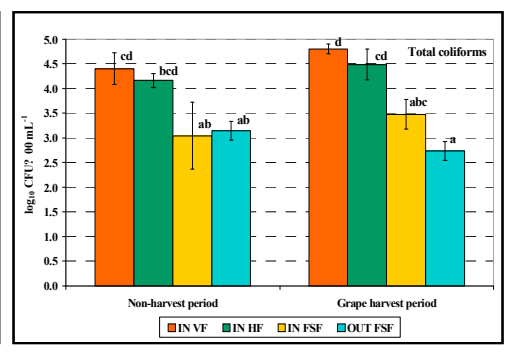

(b)

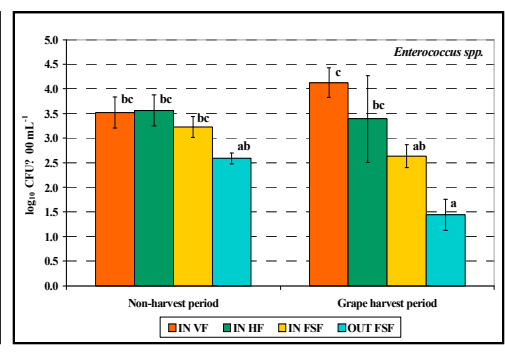

(c)

Figure 7. Average microbial counts $( \pm \mathrm{SD})$ of Escherichia coli (a), total coliform (b), and Enterococcus spp. (c) detected in water samples collected in different $\mathrm{CW}$ units during rest and grape harvest periods. Different letters indicate significant differences for $p<0.05$ for the same plant species.

Overall, total coliform and Enterococcus spp. did not show statistically significant differences in the VF influent during the monitoring periods. Different results were obtained for E.coli, which exhibited a higher count during the harvest period. Evaluating the reduction of the considered microbiological indicators, the highest removal efficiency was observed during the harvest period. In fact, the $C W$ treatment determined a mean reduction of $2.3 \mathrm{log}$ units for all the microbial groups under study. During the remaining periods, the total coliform count exhibited a statistically significant reduction of $1.26 \mathrm{log}$ units. The highest removal efficiencies detected during the harvest period were probably related to (i) the higher loading rate, which, as reported in numerous published studies [32], appears to be positively related to the efficiency; (ii) wastewater's $\mathrm{pH}$ values lower than the optimal growth $\mathrm{pH}$ range of faecal bacteria, which is between 5.5 to 7.5 [33].

The presence of E.coli contamination in winery wastewater is related to the presence of domestic constituents (i.e., toilet use by workers). Generally, faecal bacteria are present in very small quantities in the winery wastewater [34]. However, also Rozema et al. [35] report similar E.coli concentrations in the influent of $\mathrm{CW}$ treating winery process water and domestic sewage at a winery in Niagara region of Ontario (Canada).

\subsection{Winery Wastewater Reuse Option}

Table 2 shows the percentages of wastewater samples that have been below the limits of Italian legislation (M.D. 185/2003) and EU proposal regulation on the minimum requirement for water reuse.

In particular, COD concentrations have always been below the limit imposed by Italian legislation for wastewater reuse. The FSF system has proven to be indispensable to meet this legal requirement; in fact, at the HF outlet, the percentage of samples that met the legal limit for COD was $86 \%$ and increased to $100 \%$ after the FSF treatment.

Only $34 \%$ and $18 \%$ of the wastewater samples at the CW outlet exceeded the concentrations of TSS $\left(10 \mathrm{mg} \cdot \mathrm{L}^{-1}\right)$ and BOD $5\left(20 \mathrm{mg} \cdot \mathrm{L}^{-1}\right)$, respectively, set by M.D. 185/2003. This could be explained by the algae growth that occurs in the FSF stage, which increased the TSS and, consequently, the BOD 5 concentrations in the effluent.

The TN concentrations were always below the Italian reuse limit $\left(35 \mathrm{mg} \cdot \mathrm{L}^{-1}\right)$ already at the VF stage, demonstrating the low concentrations of nutrients that characterize wastewater from wineries.

Even though the multistage CW treatment was able to set a reduction of the microbial population, the $E$. coli cell density in the $60 \%$ of samples collected at the FSF effluent was higher than the threshold fixed by the M.D. $185 / 2003$ (80\% equal to $10 \mathrm{CFU} \cdot 100 \mathrm{~mL}^{-1}$ with a maximum admitted value equal to $\left.100 \mathrm{CFU} \cdot 100 \mathrm{~mL}^{-1}\right)$. 
Table 2. Percentage, for each CW unit outlet, of wastewater samples below the Italian law limits and EU proposal regulation on minimum requirements for water reuse.

\begin{tabular}{|c|c|c|c|c|c|}
\hline \multirow{2}{*}{$\begin{array}{c}\text { WW Main Quality } \\
\text { Characteristics and Location }\end{array}$} & \multirow{2}{*}{$\begin{array}{l}\text { WW Italian Law Limits } \\
\text { for Agricultural Reuse }\end{array}$} & \multirow{2}{*}{$\begin{array}{l}\text { \% Samples under Reuse } \\
\text { Italian Law Limits }\end{array}$} & \multicolumn{2}{|c|}{ EU Proposal Regulation } & \multirow{2}{*}{$\begin{array}{l}\text { \% Samples Compliant with } \\
\text { EU Regulation Requirements }\end{array}$} \\
\hline & & & Quality Requirements & Water Quality Class a & \\
\hline TSS & $10 \mathrm{mg} \cdot \mathrm{L}^{-1}$ & & $10-35 \mathrm{mg} \cdot \mathrm{L}^{-1}$ & $\mathrm{~A}-\mathrm{B}, \mathrm{C}, \mathrm{D}$ & \\
\hline Inlet VF & & 16 & & & $16-22$ \\
\hline Outlet VF & & 40 & & & $40-56$ \\
\hline Outlet HF & & 58 & & & $58-76$ \\
\hline Outlet FSF & & 66 & & & $66-100$ \\
\hline $\mathrm{BOD}_{5}$ & $20 \mathrm{mg} \cdot \mathrm{L}^{-1}$ & & $10-25 \mathrm{mg} \cdot \mathrm{L}^{-1}$ & $\mathrm{~A}-\mathrm{B}, \mathrm{C}, \mathrm{D}$ & \\
\hline Outlet VF & & 46 & & & $32-52$ \\
\hline Outlet HF & & 68 & & & $48-68$ \\
\hline Outlet FSF & & 82 & & & $64-86$ \\
\hline COD & $100 \mathrm{mg} \cdot \mathrm{L}^{-1}$ & & - & & \\
\hline Inlet VF & & 48 & & & \\
\hline Outlet VF & & 64 & & & \\
\hline Outlet HF & & 86 & & & \\
\hline Outlet FSF & & 100 & & & \\
\hline $\mathrm{TN}$ & $35 \mathrm{mg} \cdot \mathrm{L}^{-1}$ & & - & & \\
\hline Outlet VF & & 100 & & & \\
\hline Outlet HF & & 100 & & & \\
\hline Outlet FSF & & 100 & & & \\
\hline E. coli & $\begin{array}{c}50^{\mathrm{b}}-200^{\mathrm{c}} \\
\text { CFU } 100 \mathrm{~mL}^{-1}\end{array}$ & & $\begin{array}{c}10-100-1000-10,000 \\
\text { CFU } 100 \mathrm{~mL}^{-1}\end{array}$ & A-B-C-D & \\
\hline Inlet VF & & $20-40$ & & & $20-40-40-40$ \\
\hline Outlet VF & & $20-40$ & & & $20-40-60-100$ \\
\hline Outlet HF & & $20-60$ & & & $20-40-80-100$ \\
\hline Outlet FSF & & $40-60$ & & & $40-40-100-100$ \\
\hline
\end{tabular}

a Classes of reclaimed water quality and allowed agricultural use and irrigation method. Class A: All food crops, including root crops consumed raw and food crops where the edible part is in direct contact with reclaimed water. All irrigation methods allowed. Class B: Food crops consumed raw where the edible part is produced above ground and is not in direct contact with reclaimed water; processed food crops and non-food crops including crops to feed milk- or meat-producing animals. All irrigation methods allowed. Class C: The same crop category irrigable with water quality of Class B. Only drip irrigation or other methods that avoid direct contact with the edible part of the crop are admitted. Class D: Industrial, energy, and seeded crops. All irrigation methods allowed. ${ }^{\mathbf{b}} 80 \%$ of samples. ${ }^{\mathbf{c}}$ Max value. 
Considering the EU minimum quality requirements for water reuse, treated wastewater herein analysed can be included in class C (characterized by TSS and E.coli limits equal to $35 \mathrm{mg} \cdot \mathrm{L}^{-1}$ and 1000 CFU. $100 \mathrm{~mL}^{-1}$, respectively), except for $14 \%$ of samples that exceeded the concentration of $25 \mathrm{mg} \cdot \mathrm{L}^{-1}$ fixed for the $\mathrm{BOD}_{5}$. However, the observed values of this latter parameter (mean of $17 \mathrm{mg} \cdot \mathrm{L}^{-1}$ with a maximum of $65 \mathrm{mg} \cdot \mathrm{L}^{-1}$ ) may not be considered a limiting factor for $\mathrm{CW}$ effluent reuse for irrigation, which can represent a source of organic matter with high agronomic potential [36-38].

\subsection{Characteristics of Vegetated Areas in the Multistage CW}

Average wetland plant density was affected by the age of plantation with a significant increase from 2014 to 2016 (Figure 8). This plant feature remained pretty steady in the two last years of trial, with the exception of Phragmites australis, which significantly decreased from $284 \pm 28 \mathrm{plant} \cdot \mathrm{m}^{-2}$ to $178 \pm 41$ plant $\cdot \mathrm{m}^{-2}$. This reduction in the plant density (about $38 \%$ ) caused a decrease of Phragmites australis biomass dry yield (66\% in 2017) (Figure 8). However, despite this reduction, Phragmites australis showed the highest values of dry biomass, with a total mean value of about $2600 \mathrm{~g} \cdot \mathrm{m}^{-2}$, followed by Cyperus papyrus and Canna indica.



(a)

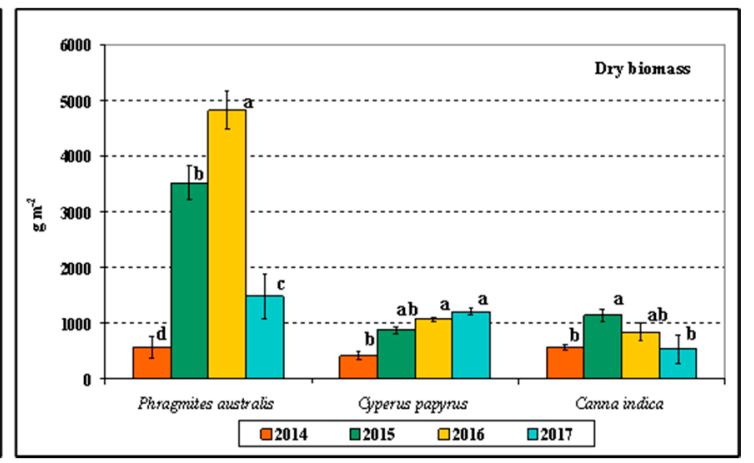

(b)

Figure 8. Average plant density (a) and dry biomass production (b) $( \pm \mathrm{SD})$ of $\mathrm{CW}$ plant species for each year of trial. Different letters indicate significant statistical differences for $p<0.05$ for the same plant species.

The dry yield of Phragmites australis was lower than that measured in other studies conducted in similar climatic conditions, but in line with CWs treating municipal wastewater, characterized by lower COD and higher nutrient concentrations [39,40]. Arienzo et al. [8] reported that winery wastewater did not produce phytotoxic effects on Phragmites australis planted in microcosm wetland at pollutant concentrations comparable to those of our wastewater. Therefore, differences in biomass yield performance shown in our study may be linked to the highest organic matter which is able to modify nutrient availability to plants via complexation, chelation, and ion exchange [41] and is associated with the low concentrations of nutrients easily assimilable (average $\mathrm{NH}_{4}$ value in VF influent of $3.5 \pm 3.7 \mathrm{mg} \cdot \mathrm{L}^{-1}$ ). This has been proven by the fertilization carried out in March 2015 that was able to significantly increase the plants' density and, consequently, the biomass production, which reached the maximum value during the following year.

The Cyperus papyrus showed less sensitivity to nutrient deficiency, highlighting a constant biomass yield after the first growing season and reaching an average plant height of about $2.5 \mathrm{~m}$. The high growth of Cyperus papyrus caused a partial shading of the area occupied by the Canna indica which has significantly reduced its biomass.

The green areas close to the multistage CW showed regular growth and vegetative development with the absence of symptoms of chlorosis or necrosis related to the phytotoxic effects of irrigation with wastewater from the winery. This result was also favoured by the sandy loam characteristics of 
the CW substrate and by the high irrigation volumes (average value of about $900 \mathrm{~mm} / \mathrm{year}$ ) which, despite the long period of absence of rainfall, prevented the accumulation of soluble salts in the root zone by leaching.

\section{Conclusions}

The multistage CW system, used for the treatment of wastewater from a small winery located in southern Italy, has a strong buffer capacity able to mitigate the large fluctuations of concentrations in the influent, with an average efficiency of removal of about $69 \%$ for TSS, $78 \%$ for COD, and $81 \%$ for $\mathrm{BOD}_{5}$. The average nutrient removal efficiency was low. This was probably due to the low influent nutrient values, already close to the background concentration. Regarding the option of wastewater reuse for irrigation, the study showed that the $\mathrm{CW}$ effluent meets the limit of the Italian legislation for COD, while, due to the algae growth process, TSS and $\mathrm{BOD}_{5}$ were found higher than the legal threshold for $34 \%$ and $18 \%$ of the analysed samples, respectively. A complete compliance with the legal limits could be obtained by increasing the filtering surface in the terminal section of FSF. A gravel material with a diameter of 10-25 mm, less than the 80-100 mm used in the CW pilot plant, could be adopted.

Despite the high levels of E.coli (up to $4.8 \mathrm{log}$ units) of the CW influent, following the sewage component of the wastewater, the bacteriological quality of the effluent (outlet of FSF unit) meets the C category standard of the EU regulation proposal for water reuse.

The low concentrations of nutrients in the CW influent determined the need to use fertilizers to promote the growth of Phragmites australis in the first CW stage. The fertilizer can be applied in raw wastewater or on the surface of the $\mathrm{CW}$ beds at the beginning of each growing season to prevent macrophyte growth problems.

The plant species present in the green area close to the multistage $\mathrm{CW}$ showed regular vegetative growth and no phytotoxicity phenomena related to the use of treated wastewater. However, more reliable results on the impact of treated wastewater on the green area will only be achieved after a further irrigation season $[42,43]$.

To conclude, the results of the study confirm the high potential and efficiency of the multistage $\mathrm{CW}$ system for the treatment of wineries wastewater and subsequent reuse for irrigation. CWs are particularly suitable for medium-small wineries, where the construction and O\&M costs of conventional wastewater treatment options may not be economically sustainable for the owner.

Author Contributions: The authors contributed with equal effort to the realization of the study. They were individually involved as follows: writing-original draft preparation, M.M. and A.P.; review and editing, M.M. and S.C.; data curation and investigation, M.M., A.P., and G.L.C.; conceptualization and methodology, M.M., C.R., and G.L.C.; visualization, A.M.; supervision, S.B. All authors have read and agreed to the published version of the manuscript.

Funding: This research was supported by the Operational Programme Italia-Malta 2007-2013 through the project "Vigna Energetica-ViEnergy" and by University of Catania trough the FIR 2014 "Design and management criteria of constructed wetland systems for the wastewater treatment from wineries and retail stores in Mediterranean area".

Acknowledgments: The authors thank Marabino winery and its technical personnel, in particular to Luca Gentile, for the availability and assistance during the monitoring activities.

Conflicts of Interest: The authors declare no conflict of interest. The funders had no role in the design of the study; in the collection, analyses, or interpretation of data; in the writing of the manuscript, or in the decision to publish the results.

\section{References}

1. International Organization of Vine and Wine. Available online: http://www.oiv.int/public/medias/7044/pptoiv-2019-october-press-conference.pdf (accessed on 14 March 2020).

2. Masi, F.; Rochereau, J.; Troesch, S.; Ruiz, I.; Soto, M. Wineries wastewater treatment by constructed wetlands: A review. Water Sci. Technol. 2015, 71, 1113-1127. [CrossRef] [PubMed]

3. Andreottola, G.; Foladori, P.; Ziglio, G. Biological treatment of winery wastewater: An overview. Water Sci. Technol. 2009, 60, 1117-1125. [CrossRef] [PubMed] 
4. Ioannou, L.A.; Li Puma, L.; Fatta-Kassinos, D. Treatment of winery wastewater by physicochemical, biological and advanced processes: A review. J. Hazards Mater. 2015, 286, 343-368. [CrossRef] [PubMed]

5. Serrano, L.; de la Varga, D.; Ruiz, I.; Soto, M. Winery wastewater treatment in a hybrid constructed wetland. Ecol. Eng. 2011, 37, 744-753. [CrossRef]

6. Shepherd, H.L.; Grismer, M.E.; Tchobanoglous, G. Treatment of high-strength winery wastewater using a subsurface flow constructed wetland. Water Environ. Res. 2001, 73, 394-403. [CrossRef]

7. Conradie, A.; Sigge, G.O.; Cloete, T.E. Influence of winemaking practices on the characteristics of winery wastewater and water usage of wineries. S. Afr. J. Enol. Vitic. 2014, 35, 10-19.

8. Arienzo, M.; Christen, E.W.; Quayle, W.C. Phytotoxicity testing of winery wastewater for constructed wetlands treatment. J. Hazard. Mater. 2009, 169, 94-99. [CrossRef]

9. Petruccioli, M.; Duarte, J.C.; Eusebio, A.; Federici, F. Aerobic treatment of winery wastewater using a jet-loop activated sludge reactor. Process Biochem. 2002, 37, 821-829. [CrossRef]

10. Strong, P.J.; Burgess, J.E. Treatment methods for wine-related ad distillery wastewaters: A review. Bioremediat. J. 2008, 12, 70-87. [CrossRef]

11. European Commission. Commission Recommendation of 6 May 2003 Concerning the Definition of Micro, Small and Medium-Sized Enterprises; 2003/361/EC. Available online: http://eur-lex.europa.eu/legal-content/ EN/AUTO/?uri=uriserv:OJ.L_.2003.124.01.0036.01.ENG (accessed on 28 April 2020).

12. Litaor, M.I.; Meir-Dinar, N.; Castro, B.; Azaizeh, H.; Rytwo, G.; Levi, N.; Levi, M.; MarChaim, U. Treatment of winery wastewater with aerated cells mobile system. Environ. Nanotechnol. Monit. Manag. 2015, 4, 17-26. [CrossRef]

13. Sheridan, C.M.; Glasser, D.; Hildebrandt, D. Estimating rate constants of contaminant removal in constructed wetlands treating winery effluent: A comparison of three different methods. Process Saf. Environ. Prot. 2014, 92, 903-916. [CrossRef]

14. Vymazal, J. The use constructed wetlands with horizontal sub-surface flow for various types of wastewater. Ecol. Eng. 2009, 35, 1-17. [CrossRef]

15. Mulidzi, A.R. Winery and distillery wastewater treatment by constructed wetland with shorter retention time. Water. Sci. Technol. 2010, 61, 2611-2615. [CrossRef] [PubMed]

16. Grismer, M.E.; Shepherd, H.L. Plants in constructed wetlands help to treat agricultural processing wastewaters. Calif. Agric. 2011, 65, 73-79. [CrossRef]

17. Decree of Ministry for Environment, n. 185, 23/07/2003, Gazzetta Ufficiale n. 169. Italian Technical Guidelines for Wastewater Reuse. Available online: http://www.gazzettaufficiale.it/eli/id/2003/07/23/003G0210/sg (accessed on 28 April 2020).

18. Marzo, A.; Ventura, D.; Cirelli, G.L.; Aiello, R.; Vanella, D.; Rapisarda, R.; Barbagallo, S.; Consoli, S. Hydraulic reliability of a horizontal wetland for wastewater treatment in Sicily. Sci. Total Environ. 2018, 636, 94-106. [CrossRef]

19. Barbera, A.C.; Cirelli, G.L.; Di Silvestro, I.; Pacifici, P.; Castiglione, V.; Toscano, A.; Milani, M. Growth and biomass production of different plant species in two different constructed wetland systems in Sicily. Desalination 2009, 246, 129-136. [CrossRef]

20. Pignatti, S. Flora d'Italia; Edagricole: Bologna, Italy, 1982.

21. APHA/AWWA/WEF. Standard Methods for the Examination of Water and Wastewater; Baltimore: American Public Health Association (APHA), American Water-Works Association (AWWA), and American Environment Federation (AEF): Washington, DC, USA, 2005.

22. APHA. Standard Methods for the Examination of Water; American Public Health Association: New York, NY, USA, 2006.

23. Russo, N.; Marzo, A.; Randazzo, C.; Caggia, C.; Toscano, A.; Cirelli, G.L. Constructed wetlands combined with disinfection systems for removal of urban wastewater contaminants. Sci. Total Environ. 2019, 656, 558-566. [CrossRef] [PubMed]

24. ISO. Water quality-Detection and enumeration of Escherichia coli and coliform bacteria-Part 1: Membrane filtration method 9308-1:2001; International Organization for Standardization: Geneva, Switzerland, 2012.

25. European Commission. Proposal for a Regulation of the European Parliament and on the Council on Minimum Requirements for Water Reuse. 28.5.2018 COM (2018) 337 final 2018/0169 (COD). 2018. Available online: http://ec.europa.eu/environment/water/pdf/water_reuse_regulation.pdf (accessed on 28 April 2020). 
26. Grismer, M.E.; Carr, M.A.; Shepherd, H.L. Evaluation of constructed wetland treatment performance for winery wastewater. Water Environ. Res. 2003, 75, 412-421. [CrossRef]

27. Zanieri, L.; Bracali, M.; Bresciani, R.; Masi, F. Multi-stage CW system for winery wastewater treatment. In Proceedings of the 12th International Conference on Wetland Systems for Water Pollution Control, Venice, Italy, 4-9 October 2010; Masi, F., Nivala, J., Eds.; International Water Association: London, UK, 2010; pp. 1139-1144.

28. Rochard, J.; Oldano, A.; Marengo, D. Environmental innovation in winery effluent management: Use of reed beds. In Proceedings of the 12th International Conference on Wetland Systems for Water Pollution Control, Venice, Italy, 4-9 October 2010; Masi, F., Nivala, J., Eds.; International Water Association: London, UK, 2010; pp. 1454-1459.

29. Kim, B.; Gautier, M.; Prost Boucle, S.; Molle, P.; Michel, P.; Gourdon, R. Performance evaluation of partially saturated vertical-flow constructed wetland with trickling filter and chemical precipitation for domestic and winery wastewater treatment. Ecol. Eng. 2014, 71, 41-47. [CrossRef]

30. Masi, F.; Conte, G.; Martinuzzi, N.; Pucci, B. Winery high organic content wastewater treated by constructed wetland in Mediterranean climate. In Proceedings of the 8th International Conference on Wetland System for Water Pollution Control, Arusha, Tanzania, 16-19 September 2002; IWA and University of Dar El Salaam: Arusha, Tanzania, 2002; pp. 274-282.

31. Kadlec, R.H.; Knight, R.L. Treatment Wetlands; Lewis Publishers: New York, NY, USA, 1996.

32. Shingare, R.P.; Thawale, P.R.; Raghunathan, K.; Mishra, A.; Kumar, S. Constructed wetland for wastewater reuse: Role and efficiency in removing enteric pathogens. J. Environ. Manag. 2019, 246, 444-461. [CrossRef]

33. McFeters, G.A.; Stuart, D.G. Survival of coliform bacteria in natural waters-field and laboratory studies with membrane-filter chambers. Appl. Microbiol. 1972, 24, 805-811. [CrossRef] [PubMed]

34. Jourjon, F.; Khaldi, S.; Reveiller, M.; Thibault, C.; Poulard, A.; Chretien, P.; Bednar, J. Microbiological characterization of winery effluents: An inventory of the sites for different treatment systems. Water Sci. Technol. 2005, 51, 19-26. [CrossRef] [PubMed]

35. Rozema, E.R.; Rozema, L.R.; Zheng, Y. A vertical flow constructed wetland for the treatment of winery process water and domestic sewage in Ontario, Canada: Six years of performance data. Ecol. Eng. 2016, 86, 262-268. [CrossRef]

36. Salgot, M.; Oron, G.; Cirelli, G.L.; Dalezios, N.R.; Díaz, A.; Angelakis, A.N. Criteria for wastewater treatment and reuse under water scarcity (Chapter 14). In Handbook of Drought and Water Scarcity: Environmental Impacts and Analysis of Drought and Water Scarcity; Eslamian, S., Eslamian, F.A., Eds.; CRC Press: New York, NY, USA, 2017; pp. 252-272.

37. Barbera, A.C.; Maucieri, C.; Ioppolo, A.; Milani, M.; Cavallaro, V. Effects of olive mill wastewater physico-chemical treatments on polyphenol abatement and Italian ryegrass (Lolium multiflorum L.) germinability. Water Res. 2014, 52, 275-281. [CrossRef] [PubMed]

38. Maucieri, C.; Cavallaro, V.; Caruso, C.; Borin, M.; Milani, M.; Barbera, A.C. Sorghum biomass production for energy purpose using treated urban wastewater and different fertilization in a mediterranean environment. Agriculture 2016, 6, 67. [CrossRef]

39. Milani, M.; Toscano, A. Evapotranspiration from pilot-scale constructed wetland planted with Phragmites australis in a Mediterranean environment. J. Environ. Sci. Health Part A 2013, 48, 568-580. [CrossRef]

40. Milani, M.; Marzo, A.; Toscano, A.; Consoli, S.; Cirelli, G.L.; Ventura, D.; Barbagallo, S. Evapotranspiration from horizontal subsurface flow constructed wetlands planted with different perennial plant species. Water 2019, 11, 2159. [CrossRef]

41. Tanner, C.C. Growth and nutrition of Schoenoplectus validus in agricultural wastewaters. Aquat. Bot. 1994, 47, 131-153.

42. Aiello, R.; Cirelli, G.L.; Consoli, S. Effect of reclaimed wastewater irrigation on soil and tomato fruits: A case study in Sicily (Italy). Agr. Water Manag. 2007, 93, 65-72. [CrossRef]

43. Barbagallo, S.; Barbera, A.C.; Cirelli, G.L.; Milani, M.; Toscano, A. Reuse of constructed wetland effluents for irrigation of energy crops. Water Sci. Technol. 2014, 70, 1032-1039. [CrossRef]

(C) 2020 by the authors. Licensee MDPI, Basel, Switzerland. This article is an open access article distributed under the terms and conditions of the Creative Commons Attribution (CC BY) license (http://creativecommons.org/licenses/by/4.0/). 